Syntax Idea: p-ISSN: 2684-6853 e-ISSN: 2684-883X

Vol. 3, No. 8, Agustus 2021

\title{
PENERAPAN MODEL PROBLEM BASED LEARNING UNTUK MENINGKATKAN AKTIFITAS DAN HASIL BELAJAR PENDIDIKAN AGAMA ISLAM SISWA
}

\section{Nurjanatin}

SMAN 1 Singkep Kecamatan Singkep, Kabupaten Lingga Riau, Indonesia

Email: nurjanatinns@gmail.com

\begin{abstract}
Abstrak
Pendidikan Agama Islam merupakan mata pelajaran pokok yang tidak hanya mengantarkan peserta didik untuk dapat menguasai berbagai kajian keislaman, tetapi lebih menekankan pada pengamalan dalam kehidupan sehari-hari di tengahtengah masyarakat. Oleh karena itu guru Pendidikan Agama Islam hendaknya dapat mengembangkan pembelajaran yang berorientasi pada pencapaian kompetensi peserta didik secara menyeluruh yang mencakup ranah kognitif, afektif dan psikomotor. Dalam pembelajaran Pendidikan Agama Islam menggunakan model Problem Based Learning menjadi sebuah pendekatan pembelajaran yang berusaha menerapkan masalah yang terjadi dalam dunia nyata sebagai sebuah konteks bagi para peserta didik dalam berlatih bagaimana cara berfikir kritis dan mendapatkan keterampilan dalam pemecahan masalah. Penelitian tindakan kelas ini dilaksanakan di SMA Negeri 1 Singkep pada siswa kelas XI MIPA.2 pada semester genap tahun pelajaran 2019/2020. Penelitian dilaksanakan mulai bulan JanuariMaret 2020. Jumlah siswa sebanyak 27 orang. Data dalam penelitian ini berupa, aktifitas belajar siswa, dan hasil evaluasi belajar. Pengumpulan data dalam penelitian ini menggunakan lembar observasi/ pengamatan dan tes soal. Hasil belajar siswa mengalami peningkatan pada siklus I rata-rata 75,7 menjadi pada siklus II rata-rata 80,0. Sedangkan tingkat ketuntasan mengalami peningkatan secara signifikan yaitu dari 21 siswa yang tuntas atau sebesar $77,8 \%$ pada siklus I meningkat menjadi 25 siswa yang tuntas atau sebesar $92,60 \%$ pada siklus II.
\end{abstract}

Kata Kunci: hasil belajar; model problem based learning

\section{Abstract}

Islamic Religious Education is a main subject that not only leads students to be able to master various Islamic studies, but places more emphasis on practice in everyday life in the midst of society. Therefore, Islamic Religious Education teachers should be able to develop learning that is oriented towards the achievement of student competencies as a whole which includes the cognitive, affective and psychomotor domains. In learning Islamic Religious Education using the Problem Based Learning model into a learning approach that seeks to apply problems that occur in the real world as a context for students to practice how to think critically and gain skills in problem solving. This classroom action research was carried out at SMA Negeri 1 Singkep in class XI MIPA.2 students in the even semester of the 2019/2020 school year. The research was carried out from January

\begin{tabular}{ll}
\hline How to cite: & Nurjanatin N. (2021) Penerapan Model Problem Based Learning untuk Meningkatkan Aktifitas dan \\
& Hasil Belajar Pendidikan Agama Islam Siswa, Syntax Idea, 3(8), https://doi.org/10.36418/syntax- \\
& idea.v3i8.1413 \\
E-ISSN: & 2684-883X \\
Published by: & Ridwan Institute
\end{tabular}


to March 2020. The number of students was 27 people. The data in this study are in the form of student learning activities, and the results of learning evaluations. Collecting data in this study using observation sheets and test questions. Student learning outcomes have increased in the first cycle an average of 75.7 to an average of 80.0 in the second cycle. While the level of completeness has increased significantly, from 21 students who completed or $77.8 \%$ in the first cycle increased to 25 students who completed or $92.60 \%$ in the second cycle.

Keywords: learning outcomes; problem based learning model

\section{Pendahuluan}

Pendidikan agama Islam adalah salah satu pembelajaran yang wajib diajarkan di sekolah mulai dari SD sampai SMA karena pendidikan meningkatkan karakter peserta didik. Pendidikan Agama Islam merupakan mata pelajaran pokok yang tidak hanya mengantarkan peserta didik untuk dapat menguasai berbagai kajian keislaman, tetapi lebih menekankan pada pengamalan dalam kehidupan sehari-hari di tengah-tengah masyarakat. Oleh karena itu guru Pendidikan Agama Islam hendaknya dapat mengembangkan pembelajaran yang berorientasi pada pencapaian kompetensi peserta didik secara menyeluruh yang mencakup ranah kognitif, afektif dan psikomotor (Marzuki, Murdiono, \& Samsuri, 2011).

Dalam kegiatan belajar mengajar yang berlangsung telah terjadi interaksi yang bertujuan guru dan peserta didiklah yang menggerakkannya. Interaksi yang bertujuan itu disebabkan gurulah yang memaknainya dengan menciptakan lingkungan yang bernilai edukatif demi kepentingan peserta didik dalam belajar. Guru ingin memberikan layanan yang terbaik bagi peserta didik, dengan menyediakan lingkungan yang menyenangkan dan menggairahkan. Guru berusaha menjadi pembimbing yang baik dengan peranan yang arif dan bijaksana, sehingga tercipta hubungan dua arah yang harmonis antara guru dengan peserta didik (Mintono, 2018).

Ketika kegiatan belajar guru harus dengan ikhlas dalam bersikap dan berbuat, serta mau memahami peserta didiknya dengan segala konsekuensinya. Semua kendala yang ada, secara umum peserta didik belum mengetahui tentang hukum-hukum Islam sehingga dapat menghambat jalannya proses belajar mengajar, baik yang berpangkal dari perilaku peserta didik maupun yang bersumber dari luar peserta didik, karena keberhasilan belajar mengajar lebih banyak ditentukan oleh guru dalam mengelola kelas (Ansori, 2017).

Berdasarkan pengalaman guru waktu mengajar di kelas XI IPA pada tahun sebelumnya pada hasil ulangan harian diperoleh bahwa hasil belajar peserta didik pendidikan agama Islam terutama dalam memahami prinsip dan praktek ekonomi islam masih rendah dari jumlah peserta didik sebanyak 51,9\% atau sebanyak 14 orang peserta didik yang tuntas dari 27 peserta didik (Mahfud Sidiq, 2020).

Dalam mengajar, guru harus pandai menggunakan pendekatan secara arif dan bijaksana, bukan sembarangan yang bisa merugikan peserta didik. Pandangan guru terhadap peserta didik akan menentukan sikap dan perbuatan. Setiap guru tidak selalu 
mempunyai pandangan yang sama dalam menilai peserta didik. Hal ini akan mempengaruhi pendekatan yang guru ambil dalam pengajaran (Jauhar, 2018).

Berhasilnya tujuan pembelajaran ditentukan oleh banyak faktor diantaranya adalah faktor guru dalam melaksanakan proses belajar mengajar, karena guru secara langsung dapat mempengaruhi, membina dan meningkatkan kecerdasan serta keterampilan peserta didik. Untuk mengatasi permasalahan di atas dan guna mencapai tujuan pendidikan secara maksimal, peran guru sangat penting dan diharapkan guru mampu menyampaikan semua mata pelajaran yang tercantum dalam proses pembelajaran secara tepat dan sesuai dengan konsep-konsep mata pelajaran yang akan disampaikan (Rismayanti, Puspitasari, \& Cahyaningsih, 2019).

Kondisi tersebut di atas disebabkan oleh kenyataan sehari-hari yang menunjukkan bahwa peserta didik kelihatannya jenuh mengikuti pelajaran Pendidikan Agama Islam. Pembelajaran sehari-hari menggunakan metode ceramah dan latihanlatihan soal secara individual, dan tidak ada interaksi antar peserta didik yang pandai, sedang, dan normal (Ismail, 2016).

Permasalahan sebagian besar peserta didik mengeluh apabila diajak belajar pendidikan agama Islam. Sering, jika diberi tugas tidak selesai tepat waktu, dan lebih suka bermain dan mengobrol, alasannya pembelajaran Pendidikan Agama Islam membosankan dan lain-lain. Dalam hal ini penulis memilih judul penelitian "Penerapan Problem Based Learning untuk Meningkatkan Aktivitas dan Hasil Belajar Pendidikan Agama Islam Siswa pada materi Prinsip dan Praktek Ekonomi Islam Kelas XI IPA 2 SMA Negeri 1 Singkep Tahun Pelajaran 2019/2020”.

Sesuai dengan permasalahan di atas, maka tujuan penelitian ini adalah untuk mengetahui aktifitas belajar pendidikan agama Islam materi Prinsip dan Praktek Ekonomi Islam melalui model Problem Based Learning kelas XI IPA 2 SMA Negeri 1 Singkep Tahun Pelajaran 2019/2020 serta untuk mengetahui hasil belajar Pendidikan Agama Islam materi Prinsip dan Praktek Ekonomi Islam melalui model Problem Based Learning kelas XI IPA 2 SMA Negeri 1 Singkep Tahun Pelajaran 2019/2020.

\section{Metode Penelitian}

Penelitian ini dilaksanakan di kelas XI MIPA 2 SMA Negeri 1 Singkep tahun pelajaran 2019/2020. Pelaksanaan penelitian ini dimulai dari bulan Januari sampai dengan bulan Maret 2020.

Subjek penelitian adalah siswa kelas XI MIPA 2 SMA Negeri 1 Singkep Tahun Pelajaran 2019/2020 yang berjumlah 27 orang siswa terdiri laki-laki berjumlah 11 orang dan perempuan berjumlah 16 orang. Adapun sasaran dari penelitian ini adalah untuk Meningkatkan Aktivitas dan Hasil Belajar Pendidikan Agama Islam Siswa pada materi Prinsip dan Praktek Ekonomi Islam Kelas XI IPA 2 SMA Negeri 1 Singkep Tahun Pelajaran 2019/2020 dalam Penerapan Problem Based Learning.

Prosedur penelitian terdiri dari 4 tahap, yakni perencanaan, melakukan tindakan, observasi dan evaluasi. Refleksi pada setiap siklus akan berulang kembali pada siklussiklus berikutnya. Aspek yang diamati dalam setiap siklusnya adalah perilaku atau 
aktivitas siswa pada saat pemberian pembelajaran kimia terkait materi tentang kimia pokok bahasan Unsur Periode 3 dan Unsur Transisi Periode 4 dengan penerapan Model Pembelajaran Berbasis Inquiri. Dengan mengamati perubahan perubahan perilaku siswa, peneliti dapat mengetahui tingkat kemajuan belajar siswa yang akan bepengaruh terhadap hasil belajarnya.Penelitian tindakan kelas ini terdiri dari 2 siklus, siklus I terdiri dari 2 kali pertemuan dan siklus kedua terdiri dari 2 pertemuan, satu pertemuan 90 menit.

Sumber data penelitian ini adalah peserta didik kelas XI IPA.2 SMA Negeri 1 Singkep tahun pelajaran 2019/2020 yang berjumlah 27 orang peserta didik terdiri lakilaki berjumlah 11 orang dan perempuan berjumlah 16 orang. Prosedur pengumpulan data dilakukan dengan cara memberikan tes kepada sumber data, melakukan observasi dan mencatat kejadian-kejadian di lapangan. Sesuai dengan jenis data yang dikumpulkan, ada dua teknik analisis data yang digunakan, yaitu analisis kuantitatif dan analisis kualitatif. Analisis kuantitatif digunakan terhadap hasil tes, sedangkan analisis kualitatif digunakan terhadap data kualitatif yang diperoleh dari hasil pengamatan terhadap aktivitas peserta didik atau hal-hal lain yang tampak selama berlangsungnya penelitian.

\section{Hasil dan Pembahasan}

\section{A. Hasil Penelitian}

\section{Siklus 1}

Dari proses pengamatan teman sejawat (observer) mengamati guru sebagai peneliti dan peserta didik sebagai subjek didapatkan data data yang bersifat kwalitatif maupun kuantitatif. Adapun aspek yang diamati adalah keterlibatan guru dan peserta didik selama proses pembelajaran yang meliputi kegiatan awal, kegiatan inti. dan kegiatan akhir dan hasil tes. Sebagaimana yang dijelaskan di depan bahwa hasil pengamatan pada tahap kegiatan awal yang belum berhasil adalah pelaksanaan tanya jawab kurang merata, penjelasan langkah-langkah pembelajaran perlu disampaikan.

Pada tahap kegiatan inti indikator yang belum berhasil adalah kegiatan bertanya jawab, diskusi kelompok, kegiatan penyamaan persepsi, dan kegiatan individual sudah terlaksana namun belum berhasil. Agar semua peserta didik mau menjawab guru perlu memberi penguatan dan memberi saran pada peserta didik untuk berlatih mengungkapkan gagasannya, jika pertanyaannya salah akan dibantu memperbaikinya. Demikian juga penjelasan langkah-langkah pembelajaran perlu disampaikan, karena peserta didik akan tahu kegiatan berikutnya tanpa menunggu informasi dari guru (Anas \& PdI, 2014).

Pada kegiatan inti pembelajaran ada beberapa indikator yang belum berhasil yakni: kegiatan soal yang di berikan pada LKS agar peserta didik tidak menggerombrol di depan papan tulis. Demikian juga pada saat peserta didik diberi kesempatan bertanya dan menjawab pertanyaan temannya kurang berhasil karena hanya beberapa peserta didik yang mau bertanya. Agar semua peserta didik mau 
bertanya dan menjawab pertanyaan temannya karena belum terbiasa, sebaiknya diberi kesempatan untuk menuliskan pertanyaan atau jawaban pertanyaan teman. Pada saat kerja kelompok sebaiknya sebelum mulai dijelaskan perlunya kerja kelompok dan pembagian tugas dari masing-masing kelompok.

Untuk kegiatan akhir menilai sendiri hasil tes perlu dilaksanakan karena selain melatih kejujuran peserta didik juga akan mengurangi tugas guru apabila peserta didik sudah terlatih. Waktu yang digunakan untuk siklus 1 ini sampai terlambat 20 menit karena peserta didik terbiasa menerima penjelasan dari guru. Setelah pembelajaran siklus I dilaksanakan guru memberikan ulangan harian untuk mengukur hasil belajar semua peserta didik hadir yaitu 27 orang. Adapun hasilnya adalah sebagai berikut:

Tabel 1

Hasil Ulangan Harian Siklus I

\begin{tabular}{|c|c|c|c|}
\hline \multirow{2}{*}{ No } & \multirow{2}{*}{ Indikator } & \multicolumn{2}{|c|}{ Ketercapaian } \\
\hline & & Jumlah & Persentase \\
\hline 1 & Peserta didik yang telah tuntas & 21 & $77,8 \%$ \\
\hline 2 & Peserta didik yang belum tuntas & 6 & $22,2 \%$ \\
\hline \multicolumn{4}{|c|}{ Refleksi } \\
\hline & Data di Siklus I & \multicolumn{2}{|c|}{$\begin{array}{c}\text { Perencanaan Tindakan } \\
\text { pada Siklus II }\end{array}$} \\
\hline $\mathrm{Ad}$ & ningkatan keaktifan siswa. & \multicolumn{2}{|c|}{$\begin{array}{l}\text { Memotivasi siswa untuk } \\
\text { belajar lebih giat lagi. }\end{array}$} \\
\hline $\begin{array}{l}\text { Ad } \\
\text { Sis } \\
\text { Pen } \\
\text { Ad } \\
\text { tun }\end{array}$ & $\begin{array}{l}\text { ningkatan jumlah siswa yang tuntas. } \\
\text { udah mulai mau bertanya. } \\
\text { lajaran sudah berpusat pada siswa. } \\
\text { eberapa siswa yang belum aktif dan } \\
\text { ehingga perlu dilakukan siklus kedua. }\end{array}$ & $\begin{array}{l}\text { Meningkatkaı } \\
\text { siswa. }\end{array}$ & keaktifan \\
\hline
\end{tabular}

\section{Siklus 2}

Penerapan apakah model Problem Based learning pada kegiatan awal tampak pada saat guru mengadakan apersepsi dengan cara tanya jawab mengaitkan topik dengan pengetahuan awal peserta didik dengan pertanyaan. Guru menunjuk peserta didik yang mengacungkan tangan paling lama. Guru memberikan penguatan dengan mengatakan bagus, pinter, sebagai penguat. Peserta didik tampak termotivasi dan sebagian besar aktif untuk menjawab pertanyaan. Kegiatan berikutnya guru menjelaskan tujuan dan langkah-langkah pembelajaran. Penjelasan langkah-langkah ini disampaikan secara tegas dan tampak peserta didik memahami. Menyampaikan gambaran inti pembelajaran terlaksana dengan baik (Heryanto, Jaeng, \& Bennu, 2018).

Pelaksanaan tindakan pada kegiatan inti dimulai oleh guru dengan membagikan LKS. Kemudian guru menjelaskan gambar peta konsep. Tindakan 
berikutnya adalah memberi kesempatan pada peserta didik untuk bertanya dan menjawab pertanyaan temannya. Peserta didik tampaknya sudah mulai hafal langkah-langkah pembelajaran. Sebelum kerja kelompok mengerjakan LKS, guru menjelaskan guna kerja kelompok, cara kerja kelompok yang baik, pembagian tugas masing-masing anggota. Namun belum semua peserta didik aktif dalam diskusi. Anak yang pandai tampak sudah tidak sabar. Belum ada kesadaran menyampaikan pengalaman belajar kepada temannya yang kurang. Tetapi pada saat menyampaikan hasil kerja kelompok masing-masing kelompok sudah siap wakilnya. Pada kegiatan kelompok peserta didik ditugasi untuk mengerjakan LKS yang sudah diberikan.

Pada akhir kegiatan, peserta didik secara individu mengerjakan tes formatif. Peserta didik tampak aktif sesuai dengan waktu yang direncanakan. Selanjutnya peserta didik dibimbing untuk menilai hasil tesnya. Keberhasilan tindakan ini berdasarkan hasil pengamatan selama pelaksanaan tindakan dan sesudah tindakan dilaksanakan. Teman sejawat mengamati perilaku guru dan peserta didik. Adapun aspek yang diamati adalah keterlibatan guru dan peserta ddik selama proses pembelajaran yang meliputi kegiatan awal, kegiatan inti, dan kegiatan akhir (Haitami, 2011).

Berdasarkan diskusi hasil pengamatan, tindakan pada tahap kegiatan awal ini sudah terlaksana dengan baik. Tiga indikator terlaksana. Pada tahap kegiatan inti indikator yang belum berhasil adalah kegiatan diskusi kelompok dan penyamaan persepsi hasil diskusi belum terlaksana dengan baik. Untuk kegiatan akhir tindakan yang belum berhasil adalah kegiatan peserta didik menilai pekerjaan sendiri.

Setelah pembelajaran siklus II dilaksanakan guru memberikan ulangan untuk mengukur hasil belajar semua peserta didik hadir sebanyak 27 orang. Adapun hasil dari ulangan harian 2 adalah sebagai berikut:

Tabel 2

Hasil Ulangan Harian Siklus II

\begin{tabular}{cccc}
\hline \multirow{2}{*}{ No } & \multirow{2}{*}{ Indikator } & \multicolumn{2}{c}{ Ketercapaian } \\
\cline { 3 - 4 } & & Jumlah & Persentase \\
\hline 1 & Peserta didik yang telah tuntas & 25 & $92,60 \%$ \\
\hline 2 & Peserta didik yang belum tuntas & 2 & $7,40 \%$ \\
\hline
\end{tabular}

\section{B. Pembahasan}

Dari hasil belajar peserta didik pada setiap siklus 1 dan 2 adalah sebagai beikut: 
Tabel 3

Rangkuman Hasil Aktivitas Belajar Peserta didik

\begin{tabular}{clcc}
\hline \multirow{2}{*}{ No } & \multicolumn{1}{c}{ Indikator } & \multicolumn{2}{c}{ Ketercapaian } \\
\cline { 2 - 4 } & \multicolumn{1}{c}{ Siklus I } & Siklus II \\
\hline 1 & $\begin{array}{l}\text { Peserta didik Menyimak dan memperhatikan } \\
\text { penjelasan guru }\end{array}$ & 27 & 27 \\
\hline 2 & $\begin{array}{l}\text { Peserta didik bertanya dan dijawab atau } \\
\text { direspon oleh peserta didik yang lain. }\end{array}$ & 20 & 27 \\
\hline 3 & $\begin{array}{l}\text { Peserta didik berkelompok dan mengerjakan } \\
\text { LKS }\end{array}$ & 27 & 27 \\
\hline 4 & $\begin{array}{l}\text { Secara kelompok menyampaikan hasil diskusi } \\
\text { dan ditanggapi kelompok lain. }\end{array}$ & 17 & 27 \\
\hline 5 & $\begin{array}{l}\text { Secara individu peserta didik melaksanakan } \\
\text { tugas guru }\end{array}$ & 27 & 27 \\
\hline 6 & $\begin{array}{l}\text { Peserta didik memperhatikan dan mencatat } \\
\text { hasil kesimpulan. }\end{array}$ & 27 & 27 \\
\hline
\end{tabular}

Tabel 4

Rangkuman Hasil Belajar Peserta didik

\begin{tabular}{clcc}
\hline \multirow{2}{*}{ No } & \multirow{2}{*}{ Indikator } & \multicolumn{2}{c}{ Ketercapaian } \\
\cline { 3 - 4 } & & Siklus I & Siklus II \\
\hline 1 & Peserta didik yang telah tuntas & 6 & 25 \\
\hline 2 & Peserta didik yang belum tuntas & 65 & 2 \\
\hline 3 & Nilai terendah & 90 & 75 \\
\hline 4 & Nilai tertinggi & 75,7 & 85 \\
\hline 5 & Rata-rata & & \\
\hline
\end{tabular}

\section{Refleksi Siklus ke II}

-Peserta didik yang sudah mencapai ketuntasan 92,60\%

-Aktifitas peserta didik.

-Karena hasilnya sudah sesuai dengan tujuan sehingga tidak perlu siklus berikutnya.

\section{Siklus I}

Berdasarkan hasil diskusi pada siklus 1 ada 5 indikator yang belum berhasil dalam proses pembelajaran. Sehingga dapat dikatakan bahwa keberhasilan guru baru 4 indikator dari 6 indikator yang direncanakan, atau 66,7 $\%$ (Salo \& Tulak, 2019).

Dan nilai rata-rata yang dicapai peserta didik adalah 75,7. Peserta didik yang tuntas sebanyak 21 atau sebesar $77,8 \%$, sedangkan yang tidak tuntas sebanyak 6 orang atau sebesar 22,2 \%. Nilai tertinggi yang dicapai peserta didik adalah 90, sedangkan nilai terendah yang dicapai peserta didik adalah 65 (Sulfemi, 2019). 
Dengan usaha yang maksimal dari peserta didik untuk memperoleh kepandaian maka jelaslah bahwa dari siklus 1 telah mengalami perubahan prilaku dan sikap dalam belajar sehingga secara konsekuensi maka terjadi perubahan prestasi belajar

\section{Siklus II}

Berdasarkan hasil refleksi pada siklus 2 diketahui bahwa dalam proses pembelajaran menggunakan apakah model Problem Based Learning ada 3 indikator yang belum berhasil dengan baik tetapi sudah terlaksana. Dari data yang dihimpun dari observasi pengamat didapatkan bahwa keberhasilan guru mencapai 5 indikator dari 6 indikator yang direncanakan, atau 83,3\% (Susmiati, 2021).

Berdasarkan observasi didapatkan peserta didik yang tuntas sebanyak 25 orang atau sebesar 92,60\%, sedangkan yang tidak tuntas sebanyak 2 orang atau sebesar $7,40 \%$. Nilai rata-rata yang dicapai sisa adalah 80 . Nilai tertinggi yang dicapai peserta didik adalah 90. Sedangkan nilai terendah yang dicapai peserta didik adalah 72 (Lubis, 2020).

\section{Kesimpulan}

Berdasarkan data analisis dan pembahasan maka dapat disimpulkan bahwa aktifitas dan hasil belajar mata pelajaran Pendidikan Agama Islam peserta didik kelas XI MIPA.2 SMA Negeri 1 Singkep dapat meningkat melalui model Problem Based Learning (PBL).

Berdasarkan hasil diskusi pada siklus 1 ada 5 indikator yang belum berhasil dalam proses pembelajaran. Sehingga dapat dikatakan bahwa keberhasilan guru baru 4 indikator dari 6 indikator yang direncanakan, atau 66,7 \%. Sedangkan dari data siklus II yang dihimpun dari observasi pengamat didapatkan bahwa keberhasilan guru mencapai 5 indikator dari 6 indikator yang direncanakan, atau 83,3\%.

Hasil belajar peserta didik mengalami peningkatan pada siklus I rata-rata 75,7 menjadi pada siklus II rata-rata 80.0. Sedangkan tingkat ketuntasan mengalami peningkatan secara signifikan yaitu dari 21 peserta didik yang tuntas atau sebesar 77,8\% pada siklus I meningkat menjadi 25 peserta didik yang tuntas atau sebesar 92,60 \% pada siklus II. Dari data tersebut menunjukkan apakah model Problem Based Learning (PBL) dapat secara efektif meningkatkan prestasi belajar peserta didik. 
Penerapan Model Problem Based Learning untuk Meningkatkan Aktifitas dan Hasil

Belajar Pendidikan Agama Islam Siswa

\section{BIBLIOGRAFI}

Anas, Muhammad, \& PdI, M. (2014). Mengenal Metodologi Pembelajaran. Muhammad Anas.Google Scholar

Ansori, Raden Ahmad Muhajir. (2017). Strategi Penanaman Nilai-Nilai Pendidikan Islam Pada Peserta Didik. Jurnal Pusaka, 4(2), 14-32. Google Scholar

Haitami, Zulfa. (2011). Meningkatkan Prestasi Belajar Matematika Dengan Pembelajaran Kontekstual Berbasis Questioning Pada Siswa Kelas Iv Sdi Kusuma Bangsa Munjungan Trenggalek Tahun Pelajaran 2007/2008. Google Scholar

Heryanto, A. A. Agus, Jaeng, Maxinus, \& Bennu, Sudarman. (2018). Penerapan Model Pembelajaran Berbasis Masalah (Problem Based Learning) Untuk Meningkatkan Hasil Belajar Siswa Pada Materi Penjumlahan Dan Pengurangan Bentuk Aljabar Di Kelas Vii A Smp Labschool Untad Palu. Jurnal Elektronik Pendidikan Matematika Tadulako, 6(1), 1-14. Google Scholar

Ismail, Faridah. (2016). Peningkatan Proses Pembelajaran Tentang Luas Bangun Melalui Model Kooperatif Stad Dan Kuis Pada Siswa Kelas Vi Sd Negeri 5 Teunom Kecamatan Teunom Kabupaten Aceh Jaya Tahun 2014/2015. Jurnal Serambi Akademica, 4(1). Google Scholar

Jauhar, Sitti. (2018). Pengembangan bahan ajar IPS berbasis pendekatan Sains Teknologi Masyarakat (STM) untuk meningkatkan kreativitas siswa. Seminar Nasional Pengabdian Kepada Masyarakat, 2018(1). Google Scholar

Lubis, Maulana Arafat. (2020). Peningkatan Hasil Belajar Siswa Dengan Menggunakan Media Gambar Berbasis Kolase Pada Pembelajaran Tematik Di Madrasah Ibtidaiyah Padangsidimpuan. Forum Paedagogik, 11(1), 90-105. Google Scholar

Mahfud Sidiq, S. I. D. (2020). Pengaruh Model Pembelajaran Take And Give Terhadap Hasil Belajar Siswa Pada Mata Pelajaran Pendidikan Agama Islam Kelas Xi Di Smk Miftahul Ulum Bandar Lampung. Uin Raden Intan Lampung. Google Scholar

Marzuki, Marzuki, Murdiono, Mukhamad, \& Samsuri, Samsuri. (2011). Pembinaan karakter siswa berbasis pendidikan agama. Jurnal Kependidikan: Penelitian Inovasi Pembelajaran, 41(1). Google Scholar

Mintono, Mintono. (2018). Efektivitas Antara Metode Pembelajaran Bervariasi Dengan Metode Konvensional Pada Pembelajaran Sejarah Kebudayaan Islam Kelas Vii Di Mts Muhammadiyah Kudus Tahun Pelajaran 2017/2018 (Uji Eksperimen). Iain Kudus. Google Scholar

Rismayanti, Gina, Puspitasari, Wina Dwi, \& Cahyaningsih, Ujiati. (2019). Penerapan Model Pembelajaran Cooperative Script Untuk Meningkatkan Hasil Belajar Siswa Pada Pembelajaran IPS. Prosiding Seminar Nasional Pendidikan, 1, 306-313. Google Scholar 
Nurjanatin

Salo, Eky Setiawan, \& Tulak, Topanus. (2019). Penerapan Model Pembelajaran Kooperatif Tipe STAD Untuk Meningkatkan Keaktifan Belajar Matematika Siswa Kelas IV SDN 5 Tikala Kabupaten Toraja Utara. Elementary Journal, 2(1), 1-15. Google Scholar

Sulfemi, Wahyu Bagja. (2019). Model pembelajaran kooperatif mind mapping berbantu audio visual dalam meningkatkan minat, motivasi dan hasil belajar IPS. Jurnal PIPSI (Jurnal Pendidikan IPS Indonesia), 4(1), 13-19. Google Scholar

Susmiati, Susmiati. (2021). Penggunaan Media Power Point untuk Meningkatkan Hasil Belajar Mata Pelajaran IPS Siswa Kelas V SDN 118275 Sialang Pamoran II Kecamatan Silangkitang. Jurnal Pendidikan Dan Pembelajaran Terpadu (Jppt), 3(1), 62-72. Google Scholar

Copyright holder:

Nurjanatin (2021)

First publication right:

Syntax Idea

This article is licensed under: 